\title{
HEAVY METAL AND TRACE ELEMENT BIOACCUMULATION IN MUSCLE AND LIVER OF THE MERLU (Merluccius merluccius Linneaus, 1758) FROM THE GULF OF BEJAIA IN ALGERIA
}

\author{
OURIDA ALIK $\otimes^{1,5}$, SALAH EDDINE OUDAINIA ${ }^{2}$, SOUHILA BOUCHEBBAH ${ }^{3}$, AICHA DEHBI-ZEBBOUDJ ${ }^{4}$, FATIHA \\ ZEROUALI-KHODJA ${ }^{5}$
}

\begin{abstract}
${ }^{1}$ Department of Biological Sciences and Environment, Faculty of Biological Sciences and Environment, University of A/mira Bejaïa 06000, Algeria; e-mail: aliknourida@gmail.com

${ }^{2}$ Laboratory of Marine Bio Resources; University of Badji Mokhtar. Annaba. Algeria; e-mail: aqua-shrimp@hotmail.com

${ }^{3}$ Laboratory of Ecology and Environment, Faculty of Biological Sciences and Environment, University of A/mira Bejaïa 06000, Algeria; e-mail: sousoumag12@gmail.com

${ }^{4}$ Laboratory of Applied Biochemistry, Faculty of Biological Sciences and Environment, University of A/mira, Bejaïa, 06000, Algeria; e-mail: dehbi_2000@ yahoo.fr

${ }^{5}$ Laboratory of Biological Océanography and Marine Environment, FSB-USTHB, BP 32 El Alia, Bab Ezzouar 16111, Algeria; e-mail:fatiha_alg@yahoo.fr
\end{abstract}

$\bowtie$ Corresponding author

Received: 12 November 2019 / Accepted: 20 January 2020

Abstract

Alik O., Oudainia S.E., Bouchebbah S., Dehbi-Zebboudj A., Zerouali-Khodja F.: Heavy metal and trace element bioaccumulation in muscle and liver of the merlu (Merluccius merluccius Linneaus, 1758) from the Gulf of Bejaia in Algeria. Ekológia (Bratislava), Vol. 40, No. 1, p. , 2021.

This preliminary study aims at assessing a contamination level of Bejaia Gulf by some Metallic Trace Elements (MTEs) such as zinc, iron, copper, nickel, lead and cadmium. The use of hake, Merluccius merluccius (Linneaus, 1758) as a bio-indicator of these heavy metals, made it possible to put in an obvious the presence of these micropollutants at the level of two target organs, the liver, detoxifying organ and the muscle, the most prized part by consumer. The MTE assays are performed using a Flame Atomic Absorption Spectrophotometer (FAAS). As for the fish contamination level, it is referred to the guide values of the WHO, FAO and Algerian recommendations. Within the framework of our study, the recorded values show that hake accumulates all metal pollutants being analyzed. Iron and zinc exhibit the highest concentration, the presence of nickel and copper were also recorded. Lead and cadmium have critical concentrations exceeding even Algerian standards.

These results revealed no significant difference in both sexes and in both target organs. However, the study indicates considerable contamination in young fish with significant concentrations according to established standards. These data reveal that Merluccius merluccius is a bio-indicator of marine pollution in the Gulf of Bejaia.

Key words: heavy metals bioaccumulation, Merluccius merluccius, contamination, Gulf of Bejaia.

\section{Introduction}

Metals occupy a prominent place in global economic activity playing a strategic role in some applications. The scientific and technical definition of heavy metals brings back their high density (exceeds $5 \mathrm{~g} / \mathrm{cm}^{3}$ ), their high atomic mass, and their toxic power for biological systems (INERIS, 2005). Comparatively to other contaminants, heavy metals are inorganic compounds; they are very toxic minerals, even at low concentrations of which they constitute a serious threat to human health, organisms and natural ecosystems, because of their toxicity, their persistence as well as their bioaccumulation characteristics (DeForest, Adams, 2007; Onistratenko et al., 2009). In addition, many heavy metal ions are come to be known as toxic because of their carcinogenic effects to human health (Fu, Wang, 2011, Mason et al., 2014).
Merluccius merluccius L.,1758, as a fish belonging to the Merluccidae family, has been strongly recommended as a bioindicator species for these Metallic Trace Elements (FAO/ WHO, 1972). This fish is found in the Mediterranean much more in the western than the eastern part (Recasens et al., 1998; Arneri, Morales-Nin, 2000; Morales-Nin, Moranta, 2004), and in the North-East Atlantic from England to Senegal (Sarano, 1986; Lucio et al., 2000; Piñeiro, Saínza, 2003; Murúa et al., 2006; Lannin, 2006; Domínguez-Petit, 2007).

It lives in varying depths of the continental shelf, near the coast for young fish and up to $1000 \mathrm{~m}$ deep for adults (Bouaziz, Djabali, 1998). As a result, work has been carried out on the biocontamination of xenobiotics on hake (Storelli et al., 2005; Aksu et al., 2011; Belhoucine et al., 2014). However, although they are more numerous, gaps still persist in this area in particular, because to date, no study has been carried

(C) The Author(s) 2021. This is an open access article distributed under the terms of the CC BY-NC-ND license.

https://content.sciendo.com/view/journals/eko/eko-overview.xml 


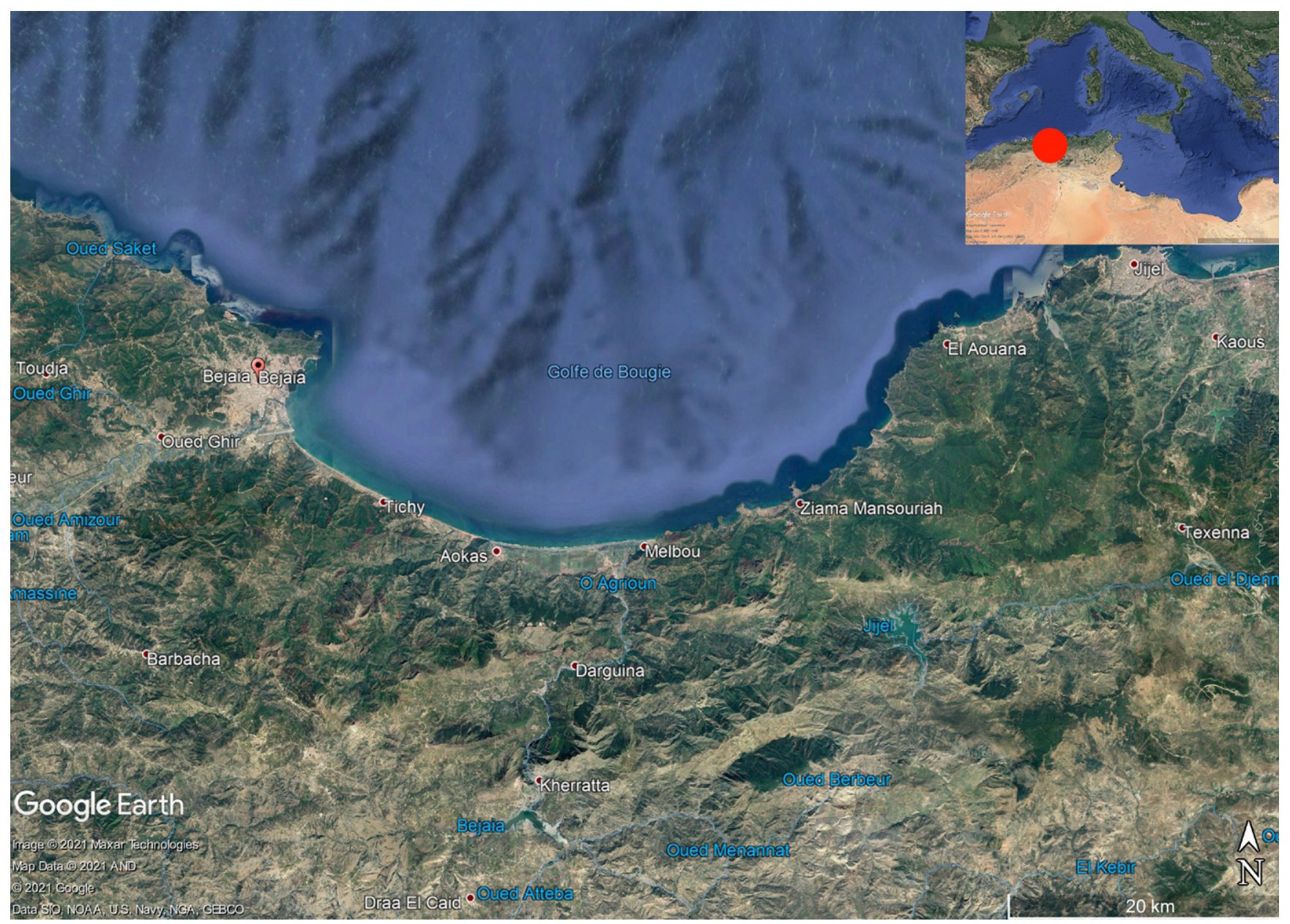

Fig. 1. Maps of Gulf of Bejaia.

out in the Gulf of Bejaia. The present work aims at evaluating the quality state of the coastal environment by Metallic Trace Elements ( $\mathrm{Cd}, \mathrm{Pb}, \mathrm{Cu}, \mathrm{Ni}, \mathrm{Fe}$ and $\mathrm{Zn}$ ) accumulated by two target organs (liver and muscle) of $M$. merluccius.

\section{Material and methods}

\section{Study area}

Bejaia region is located on the southern shore of the Mediterranean, in the eastern sector of the Algerian coast. Administratively, Bejaia is limited by five provinces: Tizi-Ouzou and Bouira in the West, Jijel in the East, Setif and Bordj Bouarreridj in the South. In the North, it opens on the Mediterranean with a length of about $100 \mathrm{~km}$ (Fig. 1). The Gulf of Bejaia is limited to the East by the Cape Cavale, to the west by Cape Carbon and open to the North on the Mediterranean.

It presents a centre of economic and industrial attraction but it is intensely stifled, particularly by the tourism sector which makes it vulnerable to any pressure.

\section{Sample analysis}

Merluccius merluccius was sampled along the Bejaia Gulf by professional fishermen. During the study period (September 2015 to September 2016), the collection of the biological material is carried out on more than 800 individuals of length ranging between 9.8 and $81.9 \mathrm{~cm}$.

Biological sampling is transported directly to the laboratory. A series of measurements are carried out on each individual, which makes it possible to separate them into lots of size and sex classes. Tissues of muscle and liver foreach sample are taken. They are dried in an oven for 24 hours at $90{ }^{\circ} \mathrm{C}$, then ground and passed through a sieve. The obtained subsamples are weighed and stored in labeled pillboxes ready for chemical analysis.

In a second step, the mineralization (dry combustion) is carried out: $2 \mathrm{~g}$ of dry weight of each sample (liver, muscle) are deposited in the tubes of the mineralizer, $1 \mathrm{ml}$ of nitric acid $\left(\mathrm{HNO}_{3}\right)$ is added at $65{ }^{\circ} \mathrm{C}$ at $65 \%$ purity and $20 \mathrm{ml}$ of double distilled water, then the whole is heated at a temperature of $100{ }^{\circ} \mathrm{C}$ for 20 minutes. After cooling, the contents are 

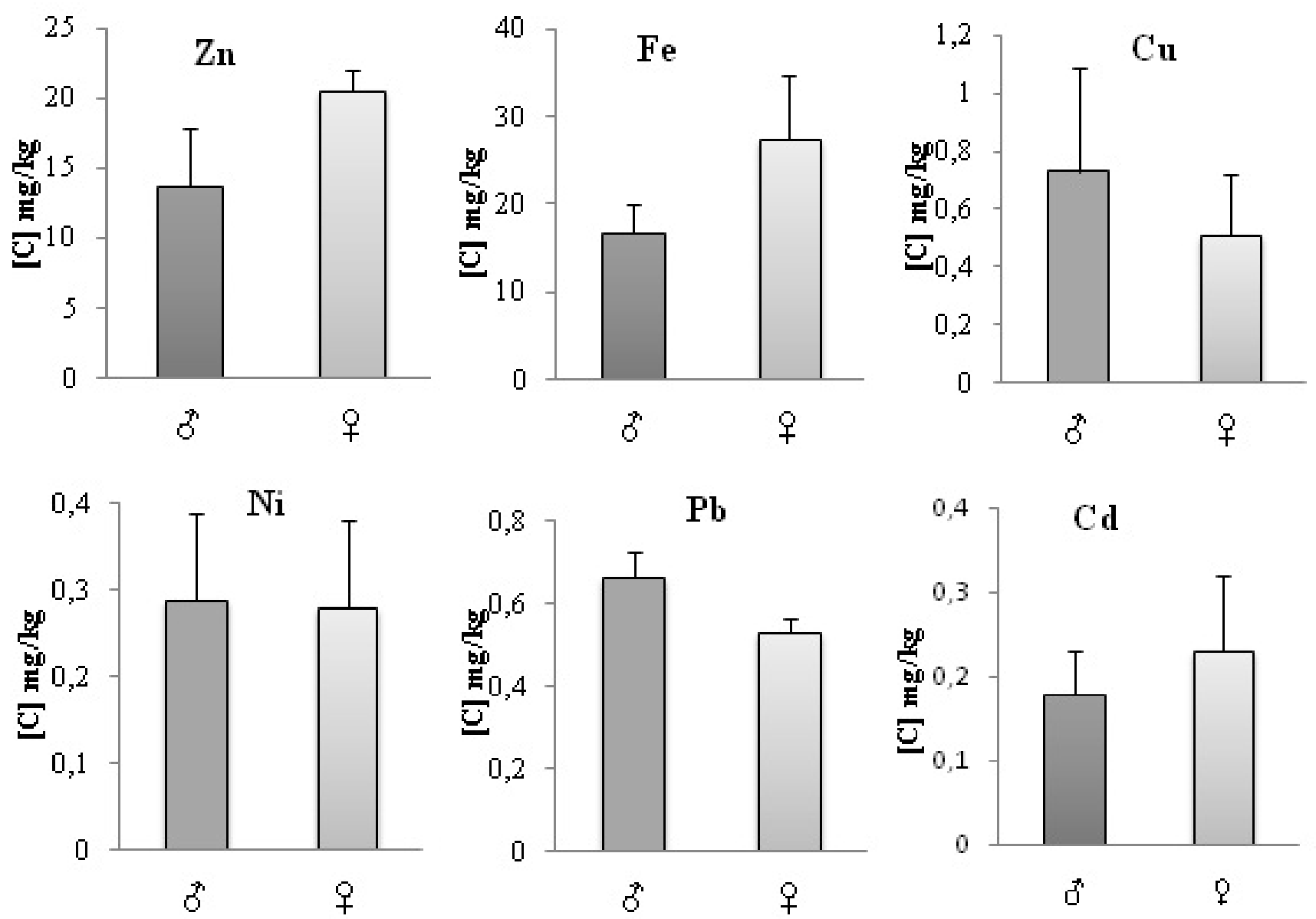

Fig. 2. Variations of mean heavy metal concentrations expressed in $\mathrm{mg} / \mathrm{kg}$ DW according to the sex of Merluccius merluccius from Bejaia Gulf.

completed with a maximum of $20 \mathrm{ml}$ of bidistilled water. After filtration, our solution is ready to be analyzed by flame atomic absorption spectrophotometer (SAA) (Amiard et al., 1987).

\section{Data analysis}

The statistical treatment of results was performed using Statistica software version 2013. To compare concentrations (mean \pm confidence interval) of heavy metals between two independent groups of the same population, the ANOVA test is applied to estimate the importance of differences between the concentrations of metallic pollutants either by target organ, by sex or size class. This difference is considered significant with a probability $(\mathrm{p})$ of less than $5 \%(\mathrm{p}<0.05)$.

\section{Preparation of calibration solutions}

The stock solutions are of the order of $1000 \mathrm{ppm}(1 \mathrm{~g} / \mathrm{l})$. In 1 liter of demineralized water, a certain quantity of chemical substances $\left(\mathrm{CuSO}_{4}, \mathrm{PbNO}_{3}\right.$, ) are dissolved in such a way as to obtain $1 \mathrm{~g}$ of each element ( $\mathrm{Cu}, \mathrm{Fe}, \mathrm{Zn}, \mathrm{Ni}, \mathrm{Pb}, \mathrm{Cd})$. A small amount of nitric acid being used as a stabilizer is added to the solutions prepared for the calibration series in order to be in the same conditions as the unknown solutions to be assayed. From the stock solution of $1 \mathrm{~g} / \mathrm{l}$, the standard solutions are prepared according to the well-defined ranges for each element.

\section{Results}

All results of targeted MTE analysis ( $\mathrm{Cu}, \mathrm{Fe}, \mathrm{Zn}, \mathrm{Pb}, \mathrm{Cd})$ obtained from hake organ samples (muscle, liver) are expressed graphically. A comparison is made between concentrations of these metals, as well as their average variation by sex, between organs independently and finally by size classes.

\section{Analysis of MTE according to sex}

The results shown in Fig. 2, explain that essential MTEs (Zn, $\mathrm{Fe}$ ) exhibit high levels, much more in females pointing out a 

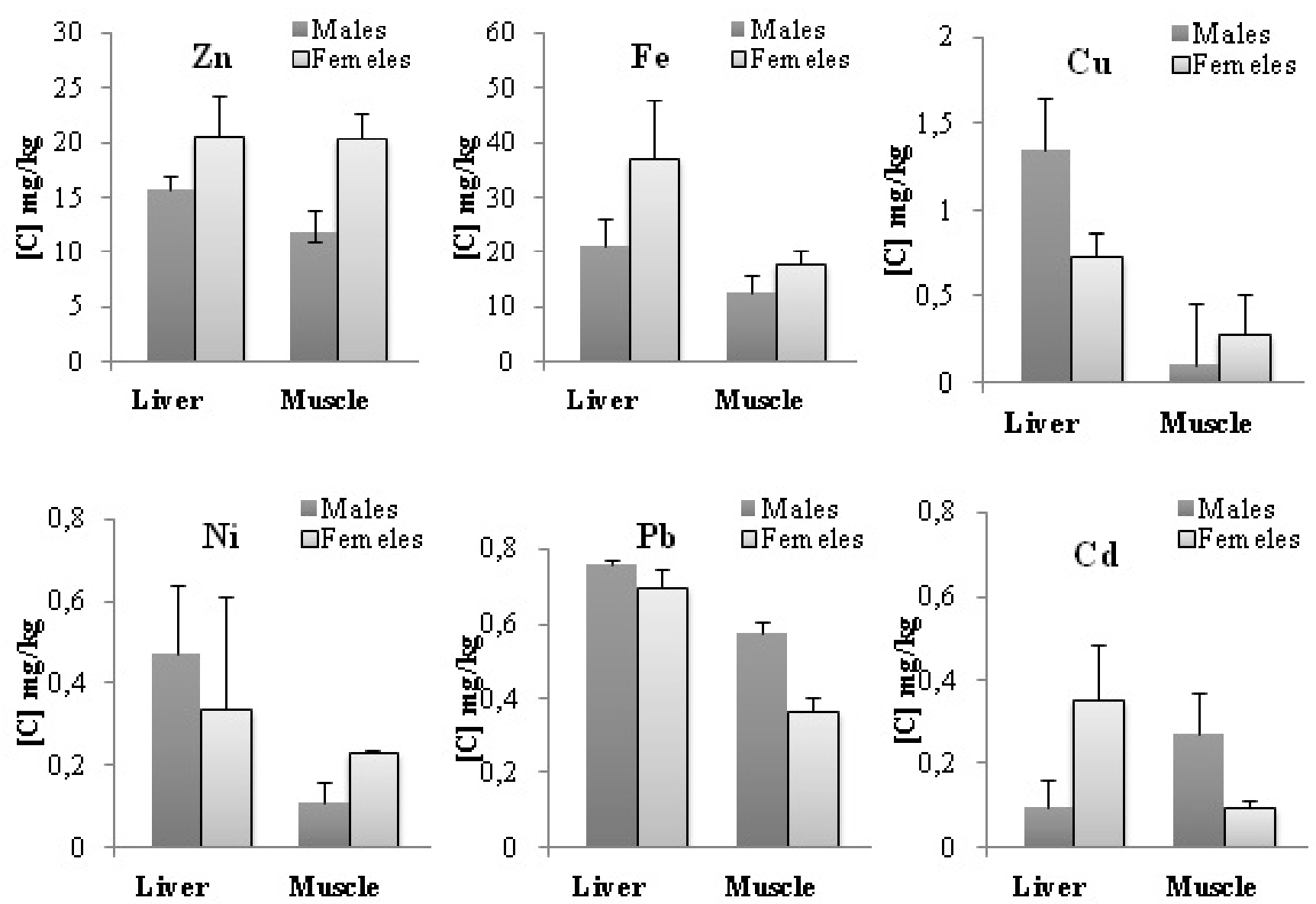

Fig. 3. Variations of mean heavy metal concentrations expressed in $\mathrm{mg} / \mathrm{kg}$ DW according to the target organs of Merluccius merluccius from Bejaia Gulf.

values of $20.57 \pm 1.39 \mathrm{mg} / \mathrm{kg} \mathrm{DW}$ and $27.51 \pm 7.22 \mathrm{mg} / \mathrm{kg} \mathrm{DW}$ respectively, for zinc and iron. However, the average concentrations in terms of essential MTEs, being recorded at lowdose $(\mathrm{Ni}, \mathrm{Cu})$ in both sexes show a significant differences at $5 \%$ level, with a higher value for copper element in males $(0.73 \pm 0.36 \mathrm{mg} / \mathrm{kg} \mathrm{DW})$. On the other hand, e mean nickel concentrations are the same for both sexes, posting up a value around $0.28 \pm 0.1 \mathrm{mg} / \mathrm{kg} \mathrm{DW}$ (Fig. 2).

Finally, non-essential MTEs ( $\mathrm{Pb}, \mathrm{Cd})$ have highly significant values $(\mathrm{p}<0.05)$ with a predominance of a higher Cd level in females recording value of $0.23 \pm 0.09 \mathrm{mg} / \mathrm{kg} \mathrm{DW}$, while $\mathrm{Pb}$ dominates in males displaying a rate of $0.67 \pm 0.06 \mathrm{mg} / \mathrm{kg}$ DW (Fig. 2).

\section{Analysis of MTE according to the organs}

Depending on organs, MTEs show that hake presents a highly significant differences $(\mathrm{F}=9.36$ and $\mathrm{p}=0.04$ ) (Fig. 3 ). The val- ues being recorded in essential MTEs in the liver show concentrations approximately twice as much in females than in males and almost twice as higher in the liver as in muscle, displaying a values of $20.63 \pm 3.72 \mathrm{mg} / \mathrm{kg}$ DWand $37.16 \pm 10.73$ $\mathrm{mg} / \mathrm{kg}$ DW respectively, for le zinc and iron.

The rest of the MTEs, indicate that they are more present in the liver of males with average concentrations exhibiting a very highly significant difference $(\mathrm{p}<0.05)$ recording values of $0.47 \pm 0.02 \mathrm{mg} / \mathrm{kg} \mathrm{DW}$ and $0.34 \pm 0.27 \mathrm{mg} / \mathrm{kg} \mathrm{DW}$ respectively, for $\mathrm{Cu}$ and $\mathrm{Ni}$ (Fig. 3).

Finally, Cd levels always significantly high in the liver, recording an average of $0.342 \pm 0.13 \mathrm{mg} / \mathrm{kg}$ DW. However, the comparison of $\mathrm{Pb}$ levels in the same context shows the existence of a very highly significant difference between the samples, always higher in the liver displaying a value of $0.76 \pm$ $0.01 \mathrm{mg} / \mathrm{kg}$ DW. (Fig.3).

These contaminants are marked in the liver with high values relative to the muscle. 

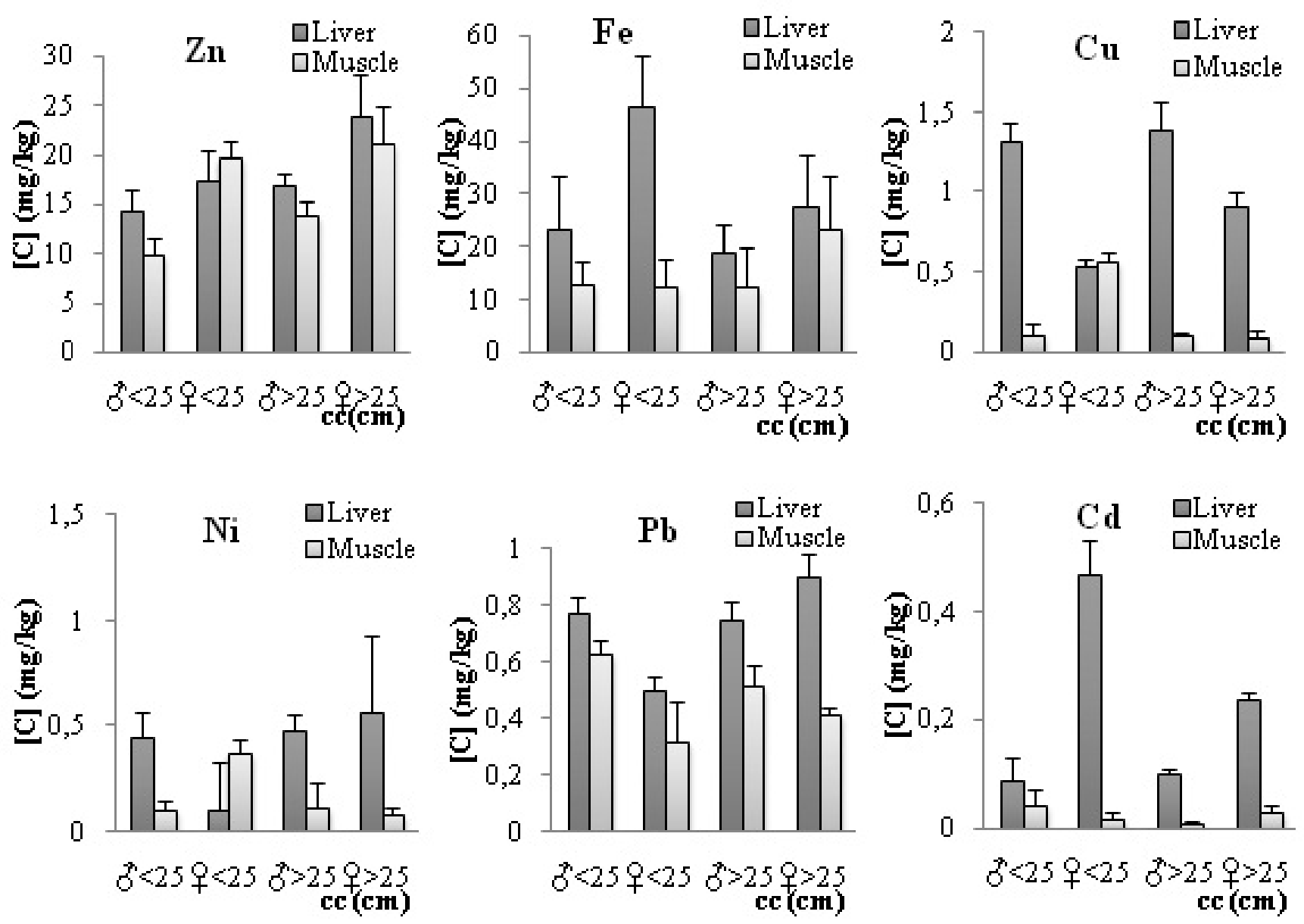

Fig. 4. Variation of mean heavy metal concentrations expressed in $\mathrm{mg} / \mathrm{kg} \mathrm{DW}$ according to the size classes of Merluccius merluccius from Bejaia Gulf.

\section{Analysis of MTE according to size classes}

Figure 4 highlights the relationship between size and sex of hake individuals and the mean levels of targeted MTEs. In the most cases, the latter are accumulated much more in liver and muscle of juvenile and adult individuals, both in male and female populations. The average concentrations of essential MTEs show that $\mathrm{Zn}$ has higher values on one side in females, and on the other hand in the size class of more than $25 \mathrm{~cm}$ for males and females. Likewise, the Fe also records higher average values in female than male population, either for juveniles or adults (Fig. 4).

From these results, it seems that the average concentrations in $\mathrm{Cu}$ and $\mathrm{Ni}$ are higher in liver of male and female adults, but they pile up much more in muscles of juvenile females. As inorganic element, the mean concentrations of $\mathrm{Cd}$ accrue in female livers as well as in juvenile male muscles; this accumulation tends to decrease with age.Also, $\mathrm{Pb}$ concentra- tions decrease with the size of individuals in male population, unlike females that stack this element with age, first in liver, then in muscle.

\section{Discussion}

Most of the time, a waste discharge is never considered as a unique source because different types of pollution are mixed and interact with each other (synergistic effects). Sources as wadis or sewers reject organic wastes and detergents, some of which are accompanied by heavy metals (chemical pollution), various microorganisms such as bacteria and viruses (biological pollution). The whole flow ultimately into the aquatic ecosystem (Physical Pollution) (Gravez, Bernard, 2006). In addition, several previous studies have shown that heavy metals are considered as contaminants in coastal and marine environments around the world, stemmed from industrial, agricultural and anthropogenic discharges (Ruilian et al., 2008; 
Table 1. Comparison of heavy metal content in the muscle in Merluccius merluccius from the Maximum Permissible Dose (MPD).

\begin{tabular}{|c|c|c|c|c|c|c|}
\hline $\begin{array}{l}\text { Metals } \\
\qquad \text { Species }\end{array}$ & Lead $(\mathrm{Pb})$ & Cadmium (Cd) & Cooper $(\mathrm{Cu})$ & Nickel (Ni) & Zinc (Zn) & Fer $(\mathrm{Fe})$ \\
\hline Fishes & $\begin{array}{c}0.5 \mathrm{mg} / \mathrm{kg} \mathrm{WW}(\mathbf{a}) \\
0.3 \mathrm{mg} / \mathrm{kg} \mathrm{WW} \mathrm{(b)} \\
0.12(\mathbf{d}) \\
0.3 \mathrm{mg} / \mathrm{kg} \mathrm{Wt} \mathrm{(e)} \\
0.3-6 \mathrm{mg} / \mathrm{kg} \mathrm{DW} \text { (f) }\end{array}$ & $\begin{array}{c}0.1 \mathrm{mg} / \mathrm{kg} \mathrm{ww} \mathrm{(a)} \\
0.05 \mathrm{mg} / \mathrm{kg} \mathrm{ww} \mathrm{(b)} \\
0.05 \mathrm{mg} / \mathrm{kg} \mathrm{ww} \mathrm{(c)} \\
0.181 \mathrm{mg} / \mathrm{kg} \mathrm{ww} \mathrm{(d)} \\
0.1 \mathrm{mg} / \mathrm{kg} \mathrm{dw} \mathrm{(e)} \\
0.15-3 \mathrm{ppm} \mathrm{DW} \mathrm{(h)}\end{array}$ & $\begin{array}{c}0.15 \mathrm{mg} / \mathrm{kg} \\
\text { ww (b,e) }\end{array}$ & $\begin{array}{l}0.5 \mathrm{mg} / \mathrm{kg} \text { ww (a) } \\
0.3 \mathrm{mg} / \mathrm{kg} \text { bw (b) }\end{array}$ & $\begin{array}{c}30 \mathrm{mg} / \mathrm{kg} \mathrm{ww}(\mathbf{a}) \\
48.5 \mathrm{mg} / \mathrm{kg} \mathrm{DW}(\mathbf{d}) \\
5 \mathrm{mg} / \mathrm{g} \mathrm{Dw}(\mathbf{g})\end{array}$ & $\begin{array}{c}50 \mathrm{mg} / \mathrm{kg} \\
\text { ww (b) }\end{array}$ \\
\hline $\begin{array}{l}\text { Present study } \\
\text { M.merluccius }\end{array}$ & 0.6 & 0.203 & 0.62 & 0.282 & 17.18 & 22.16 \\
\hline
\end{tabular}

Notes: (a) - OMS-IPCS (1998); (b) - JORADP No25 (2011); (c) - CEE (1982); (d) - IAEA (2004); (e) - FAO/WHO (2011); (f) - GIPPM (1973); (g) - NHMRC (1992); (h) - IOPR (1996); DW - dry weight; WW - wet weight.

Belhaouari et al., 2011; Onivogui et al., 2013; Abi-Ayad et al., 2018).

Heavy metals are considered as serious pollutants of the aquatic environment because of their persistence, remanance and biomagnification in the food chain (Yigit, Altindag, 2006; Guardiola et al., 2016), thus the aquatic animals may be exposed to high concentrations by these micropollutants (Kalay, Canli, 2000; Henry et al., 2004; Ribeiro et al., 2005).It must be pointed out, there are two categories of metals, those which are indispensable for life $(\mathrm{Zn}, \mathrm{Cu}, \mathrm{Ni}, \ldots)$ whose deficiency, as well as excess, can cause diseases, and those which are very toxic $(\mathrm{Cd}, \mathrm{Pb}, \mathrm{Hg})$, they are not considered as essential metals (Altindag, Yigit, 2005). Their positive role in cells, to date, is not known but they are increasingly using in industrial sectors.

Unlike other contaminants, heavy metals are inorganic compounds, highly toxic minerals, even at low concentrations either for plants or animals. They are seen as major contaminants for both terrestrial and aquatic environments (Chen et al., 2000; Lafabrie et al., 2007). The regulation of these metals has been widely described in fish literature

Generally, Lead is present in small quantities. The industry discharges, leaching from gas stations and farmlands, road traffic, lixiviation phenomenon in dumps, and atmospheric deposition contribute to the high lead load (El Morhit et al., 2013).

According to Cossa et al. (1993), Lead levels in Platichthys flesus muscle tend to decrease with size in less contaminated areas, while (Benguedda et al., 2011; Pouil et al., 2017) showed that the accumulating power of various metallic elements is different not only from one species to another, but in food webs as well.

By comparing the levels recorded by category, we found that the purely toxic elements (lead and cadmium), accumulated in the muscle tissue of Merluccius merluccius exceed the tolerated thresholds (Table 1). The average levels present in our samples are 0.6 and $0.203 \mathrm{mg} / \mathrm{kg}$ DW respectively for lead and cadmium, far exceeding the recommended standards (CEE, 1982; IOPR, 1996; WHO-IPCS, 1998; FAO/WHO, 2001; IAEA, 2004; GIPPM, 1973; JORADP N²5, 2011). Cadmium and lead, which causes dysfunctions in the renal, hepatic, gastrointestinal and reproductive systems of living beings (Amiard-Triquet et al., 1993; Mason et al., 2014). In WHO (1993) reported that cadmium, after mercury, is the most toxic of heavy metals for aquatic animals. Its presence is explained by the very frequent use of phosphate fertilization, the main source of this element, also by the littoral currents (very intense upwelling). Thus, Belhoucine et al. (2014) showed the behavior of cadmium which reveals significant variations during different periods of the year.

According to Amiard et al. (1987), lead can be biomagnified in biological systems, subsequently becoming a contaminating potential for different trophic links. The origin of the contamination by this element would be linked on one hand, to the fuel reserves stored around the Gulf of Béjaia, and on the other hand, to the important human activity (harbour, gear circulation...) that characterizes the peri-urban" part of this Gulf, while Gagneux-Moreaux (2006) reported that the most important of lead flow to the ocean comes from the atmosphere.

Our results confirm those of Nsimanda et al., (2015), indicating that adult fishes accumulate more heavy metals compared to juveniles, showing higher levels of lead than cadmium in each part of analyzed fish. The presence of lead and cadmium in coastal ecosystems is largely a reflection of anthropogenic influence, and the bioaccumulation of these elements generally depends on the availability of these metals in the environment whose the contamination remains dependent on several surrounding factors (Nacer, 2013; Kayalto et al., 2014; Chouba et al., 2016).

Sex is one of the predominant biological factors. In 2011 Lacoue-Labarthe et al., showed that from a certain stage of embryonic development of individuals, sex plays an important role in the accumulation of different Metallic Trace Elements (Cd, $\mathrm{Cu}, \mathrm{Zn} . .$. ), while Webb in 1997, announced that the sex undoubtedly, plays an important role in the distribution of MTEs.

Other authors attested that the loss of contaminants is caused by reproduction (Belhoucine et al., 2014). Spawning causes significant decontamination in females, since from their first reproduction, a clear decrease in metal pollutant concentrations is observed, While Mellon-Duval et al. (2010) 
and El Habouz et al. (2011), reported that the accumulation of these elements is the cause of the difference in growth between males and females. Eventually, the downward trend of the identified MTEs corresponds to the breeding season of Merluccius merluccius, which spreads throughout the year (Alik et al., 2016). This decontamination by female population via the egg seems to be related at least, in part, to the mobilization of metals in liver for the gonads during maturation.

The high nickel content in hake from the Gulf of Bejaia suggests that potential sources of contamination by this element would be largely, either domestic discharges or surrounding and industrial agglomerations (discharges that Soummam Wadi carries to the Gulf, Cevitale unit, Eghzar Amokrane industrial area ...). However, the hypothesis that the hydrodynamism in this part of the Gulf favoring this distribution, cannot be ruled out.

The tendency for zinc accumulation is more difficult to explain because this metal is normally regulated by marine organisms since it enters in several biological processes. Following this study, we found that, the liver and muscle tissues accumulate both zinc, but the highest concentrations are found in the liver. However, we found significant variations between the two sexes and according to the considered size classes. It is to mention that many studies highlight the affinity of $\mathrm{Zn}, \mathrm{Cu}$ and Cd in the liver (Yilmaz, 2009; Bashir et al., 2013...). This could be explained by the role of these elements in hepatic physiology as enzymatic cofactors, but also the fact that they are subject to rapid elimination by muscle (Marcovecchio, Moreno, 1993; De Conto Cinier et al., 1999).

Several studies have also shown that concentrations of these Metallic Trace Elements in marine species vary seasonally (Bei et al., 1998; Orban et al., 2002). Öztürk et al., (2009) argued that these variations codify the distribution of heavy metals playing an important role in bioaccumulation by hake. In this context, we believe that our data are comparable to those already observed, that changes in zinc seem to be closely related to seasonal phenomena. In addition, it is possible that high concentrations of zinc recorded during the summer, are attributed to the importance of water activity during this period.

The variation in the mean concentration of heavy metals appears to be related to the individual sizes; this is consistent with the results of (Coombs, 1980; Oualietal, 2018) which stated that the development (growth, size and sexual maturity) of marine organism influences the bioaccumulation of contaminants.

Metallic pollutant levels in liver of bioindicator organisms are higher than those seen in muscle. According to Ramade (1992), Metallic Trace Elements are particularly concentrated in the liver of teleosts also in the kidneys and to a lesser extent in the muscle. In the same context, Powell et al. (1981), already showed that heavy metals were concentrated in the organs of teleost fishes: Liver $>$ Kidney $>$ Muscle.

Pollutants can be immobilized in the sediment or transited to groundwater, surface water, plants, animals and humans (Rouane-Hacene et al., 2008; Ouali et al., 2018). These accumulation processes depend on assimilation rates, excretion and storage of each element.

According to our results, male individuals seem to be far from zones contaminated by these heavy metals. This can be explained by the fact that males move far from the coast and therefore far from sources of pollution. In contrast, females accumulate these elements with age; also they frequent the shoreline of the coast especially during breeding season. Huang et al. (2007), denoted that these xenobiotics are problematic because of their persistent nature and toxicity. Indeed, the regulation imposes low thresholds.

Trace Elements namely Zinc and Iron show higher levels in comparison to toxic elements; nevertheless, the levels of these elements, being respectively of the order of 17.18and $22.16 \mathrm{mg} / \mathrm{kg} \mathrm{DW}$, do not constitute a danger to consumer health, because they are below the maximum admissible dose (NHRMC, 1992; OMS-IPCS, 1998; IAEA, 2004; JORADP $\mathrm{N}^{\circ} 25,2011$ ).

From our results, it can be deduced that the average concentrations of heavy metals found in the hake from the Béjaia Gulf are alarming compared to those cited in literature as well as to allowable doses.

Reliable assessment of risks carried by these pollutants to human health and environment is a major issue (Alavanja et al., 2004). Mainly, the Metallic Trace Elements are transported in the ecosystems by atmospheric way and by means of streams, having various origins, substratum (lead ...), atmospheric pollution (lead, cadmium...), fertilizers (cadmium, lead ...), and urban sludge (mercury, lead, cadmium ...) (Chiffoleau et al., 2001; Ohta et al., 2002; Yi et al.,2011; Cassas, 2006; Borsali, 2015).

Thus, the Gulf of Bejaia is conceived as a final receptacle of many discharges (industrial and municipal), considered as the origin of contaminating metals detected in the Merluccius merluccius organs (muscle and liver). This pollution is due to the pollutant load, resulting from human and industrial activities without any treatment. The Gulf of Bejaia which is surrounded by a large hydrological network that drains heavy pollution along the wadis (Soummam and Agrioune), which flow directly to this Gulf causing ecological disasters, is responsible for repeated mortalities of different fish species almost every year.

Hazardous waste spills from industrial complexes in Sétif province (lead-based batteries), the Aïn-zada dam located in the Bordj-Bouariridj province, the Agro-food complex of Eghzar-Amokrane, Tala Hamza Zinc Project, the Cévital complex and the hydrocarbon terminal, represent serious threats to the marine environment.

The high levels are explained too, by the fact that Gulf of Bejaia is under a direct influence of the maritime traffic. However, the paints that cover hulls of boats, considered as antifouling, are based on copper compounds and / or synthetic chemicals that persist in the environment in the long term (Leroy, 2006; Augier, 2008).

It is necessary to take into account some factors such as; the area of Bejaia Gulf, the number of ships with their hulls, as well as their engine effects and gasoline vapor emissions that contribute to the pollution of the gulf. In addition other sources of pollution to be emphasized are; public dumps that pour directly into the gulf, seepage and, also water as vector, contribute to transport a various pollutants then, to integrate them into the food chain (phytoplankton, zooplankton, algae, fish ... etc.). Finally human being placed at the top of the food webs, will be exposed to all sorts of pollution. It should be 
noted that climatic conditions also play a considerable role in the fluctuations observed in the environments to be studied.

\section{Conclusion}

The bioaccumulation of heavy metals, being studied and analyzed $(\mathrm{Cd}, \mathrm{Pb}, \mathrm{Cu}, \mathrm{Ni}, \mathrm{Fe}$ and $\mathrm{Zn}$ ) takes place preferentially in the liver compared to the muscle of Merluccius merluccius. In addition, given that the Gulf of Bejaia is significantly polluted, the metal loads far exceed the recommended standards especially for inorganic elements.

These metal concentrations come probably from the industrial complexes installed along the drainage basin of Bejaia region. On the other hand, since hake is placed in higher trophic levels, the uncontrolled and anarchic consumption of seafood can carry a serious risk to population health of the region. To this end, we call on all partners in the professional, researchers and administration sectors to work together to make sure regulations are respected.

\section{References}

Abi-Ayad, L., Ghezlaoui, S.-M. B.-D., Belkhouche, N. \& Aguado J.M. (2018) Spatiotemporal bioaccumulation of lead, cadmium, zinc and copper metals in Lettuce Sea Ulva lactuca harvest in two Algerian west coasts. Ekológia (Bratislava), 37(3), 243-258. DOI: 10.2478/eko-2018-0020.

Aksu, A., Balkis, N., Taşkin, Ö.S \& Erşan M.S. (2011). Toxic metal (Pb, $\mathrm{Cd}$, As and $\mathrm{Hg}$ ) and organochlorine residue levels in Hake from the marmara Sea, Turkey. Environ. Monit. Assess., 182(1-4), 509-521. DOI: $10.1007 / \mathrm{s} 10661-011-1893-1$

Alavanja, M.C., Hoppin, J.A. \& Kamel F. (2004). Health effects of chronic pesticide exposure cancer and neurotoxicity. Annu. Rev. Public Health 25, 155-197. DOI: 10.1146/annurev.publhealth.25.101802.123020.

Alik, O., Bouchebbah, S. \& Zerouali-Khodja F. (2016). Etude histologique de l'ovogenèse du merlu (Merluccius merluccius L., 1758) de la frange côtière Est algérienne au cours du cycle sexuel. $1^{\text {er }}$ Colloque International d'Ecophysiologie Animale et Biodiversité/Maison de la Science, USTHB Alger.

Altındag, A. \& Yigit S. (2005). Assessment of heavy metal concentrations in the food web of Lake Beysehir, Turkey. Chemosphere, 60(4), 552556. DOI: 10.1016/j.chemosphere.2005.01.009.

Amiard, J.C., Pinneau, A., Boiteau, H. L., Metayer, C. \& Amiard-Triquet C. (1987). Application de la spectrometrie d'absorption atomique zeeman aux dosages de 8 elements traces $(\mathrm{Ag}, \mathrm{Cd}, \mathrm{Cr}, \mathrm{Cu}, \mathrm{Mn}, \mathrm{Ni}$ $\mathrm{Pb}, \mathrm{Se})$ dans des matrices biologiques solides. Water Res., 21(6), 693-697. DOI: 10.1016/0043-1354(87)90081-9.

Amiard-Triquet, C., Jeantet, A.Y. \& Berthet B. (1993). Metal transfer in marine food chains: bioaccumulation and toxicity. Acta Biol. Hung., 44(4), 387-409.

Arneri, E. \& Morales-Nin B. (2000). Aspects of the early life history of European hake from the central Adriatic. J. Fish Biol., 56(6), 1368-1380. DOI: $10.1111 /$ j.1095-8649.2000.tb02149.x.

Augier, H. (2008). Le livre noir de l'environnement: Etat des lieux planétaire sur les pollutions. Monaco: Editions Alphée, Jean-Paul Bertrand.

Bashir, F.H., Othman, M.S., Mazlan, A.G. \& Rahim S.M. (2013). Heavy metal concentration in fishes from the coastal waters of Kapar and Mersing, Malaysia. Turkish Journal of Fisheries and Aquatic Sciences, 13(2), 375-382. DOI: 10.4194/1303-2712-v13-2-21.

Bei, F., Catsiki, V.A. \& Stroggyloudi E. (1998).Seasonal and spatial variations of $\mathrm{Cu}, \mathrm{Cr}, \mathrm{Ni}$ and $\mathrm{Pb}$ concentrations in Mytilus galloprovincialis of Saranikos Gulf, Greece. Rapports de la Comission Internationale pour l'Exploitation Scientifique de la MerMéditerranée.

Belhaouari, B., Rouane-Hacene, O., Bouhadiba, S. \& Boutiba Z. (2011). Utilisation d'un Gastéropode marin Osilinus turbinatus en biosurveillance marin : application aux métaux lourds du littoral algérien occidental. Halieutique et Aquaculture, 1(3), 89-96. https://www.reserchgate.net/publication/317723871.
Belhoucine, F., Alioua, A., Bouhadiba, S. \& Boutiba Z. (2014). Impact of some biotics and abiotics factors on the accumulation of heavy metals by a biological model Merluccius merluccius in the bay of Oran in Algeria. Journal of Biodiversity and Environmental Sciences, 5(6), 33-44. https://www.innspub.net.

Benguedda, W., Dali Youcef, N. \& Amara R. (2011). Trace metals in sediments, macroalgae and benthic species from the western part of Algerian coast. Journal of Environmental Science and Engineering, 15(12), 1604-1612.

Borsali, S. (2015). Evaluation de la contamination métallique dans trois organes (foie, gonades et muscle) du rouget de roche (Mullus surmuletus L., 1758). Par quatre métaux lourds $(\mathrm{Zn}, \mathrm{Cu}, \mathrm{Cd}, \mathrm{Pb})$ pêché dans la baie d'Oran. Doctoral thesis, University of Oran, Algeria.

Bouaziz, A. \& Djabali F. (1998). Le merlu des côtes algériennes: Identification et répartition. In J. Lleonart (Ed.), Dynamique des populations marines (pp. 139-149). Zaragoza : CIHEAM. http://om.ciheam.org/ om/pdf/c35/98606253.pdf

Cassas, S. \& Bacherb C. (2006). Modelling trace metal ( $\mathrm{Hg}$ and $\mathrm{Pb}$ ) bioaccumulation in the Mediterranean mussel, Mytilus galloprovincialis, applied to environmental monitoring. J. Sea Res., 56(2), 168-181. DOI: $10.1016 /$ j.seares.2006.03.006.

Chen, C.Y., Stemberger, R.S., Klaue, B., Blum, J.D., Pickhardt, C. \& Folt C.L. (2000). Accumulation of heavy metals in food web components across a gradient of lakes. Limnol. Oceanogr., 45(7), 1525-1536. DOI: 10.4319/lo.2000.45.7.1525.

Chiffoleau, J.F., Auger, D., Chartier, E., Michel, P., Truquet, I., Ficht, A., Gonzalez, J.L. \& Romana L.A. (2001). Spatiotemporal changes in cadmium contamination in the Seine estuary (France). Estuaries, 24(6), 1029-1040. DOI: 10.2307/1353015.

Chouba, L., Ennouri, R., Derouiche, E. \& Tissaoui C. (2016). Etude des métaux traces $(\mathrm{Cd}, \mathrm{Pb}, \mathrm{Hg})$ dans la chair des poissons des fermes aquacoles tunisiennes. Bulletin de l'Institut National des Sciences et Technologies de la Mer de Salammbô, 43, 27-30.

C.E.E. (1982). Communication de la commission au conseil relative aux substances dangereuse susceptibles de figurer sur la liste I de la directive 76/464/CEE du conseil.

Coombs, T.L. (1980.Heavy metal pollunts in the aquatic environment. In R. Gilles (Ed.), Animals and enviromental fitness: Physiological and biochemical aspects of adaptation and ecology, (pp. 283-302). Elsevier. DOI : 10.1016/B978-0-08-024938-4.50021-5.

Cossa, D., Elbaz-Poulichet, F., Gnassia-Barelli, M. \& Romeo M. (1993) Lead in marine environment. Biogeochemistry and ecotoxicology. IFREMER. https://archimer.ifremer.fr/doc/00000/1449/.

De Conto Cinier, C., Petit-Ramel, M., Faure, R., Garin, D. \& Bouvet Y. (1997). Cadmium bioaccumulation in carp (Cyprinus carpio) tissues during long-term high exposure: analysis by inductively coupled plasma-mass spectrometry. Ecotoxicol. Environ. Saf., 38(2), 137-143. DOI: 10.1006/eesa.1997.1569.

DeForest, D. \& Adams W. (2007). Assessing metal bioaccumulation in aquatic environments: The inverse relationship between bioaccumulation factors, trophic transfer factors and exposure concentration. Aquat. Toxicol., 84(2), 236-246. DOI: 10.1016/j.aquatox.2007.02.022.

Domínguez-Petit, R. (2007). Study of reproductive potential of Merluccius merluccius in the Galician Shelf. Doctoral Thesis, University of Vigo, Spain.

El Habouz, H., Recasens, L., Kifani, S., Moukrim, A., Bouhaimi, A. \& El Ayoubi S. (2011). Maturity and batch fecundity of the European hake (Merluccius merluccius, Linnaeus, 1758) in the eastern central Atlantic. Sci. Mar., 75(3), 447-454. DOI: 10.3989/ scimar.2011.75n3447.

El Morhit, M., Belghity, D. \& El Morhit F. (2013). Metallic contamination in muscle of three fish species in the southern Atlantic coast the Laâyoune (Morocco). Larhyss Journal, 15, 21-34. http://hdl.handle. net/123456789/72.

FAO/WHO (1972). Evaluation of certain food additives and the contaminants mercury, lead and cadmium. Sixteeth Report of the Joint FAO/ WHO Expert Committee on Food Additives.

FAO/WHO (2001). Evaluation of certain food additives and contaminants. Sexty-seventh report of the Joint FAO/WHO Expert Committee on Food Addictives. 
Fu, F. \& Wang Q. (2011). Removal of heavy metal ions from wastewaters a review. J. Environ. Manag., 92(3), 407-418. DOI: 10.1016/j.jenvman.2010.11.011.

Gagneux-Moreaux, S. (2006). Les métaux ( $\mathrm{Cd}, \mathrm{Cu}, \mathrm{Pb}$ et $\mathrm{Zn})$ dans la production des micro- algues sur différents milieux de culture: Biodisponibilité- Bioaccumulation et impact physiologique. Doctoral thesis, Université de Nantes.

GIPPM (1973). Rapport du Groupe d'Etudes des Problèmes de Pollution des Mers (Interministériel), pour une politique de lutte contre la pollution desmers 1973. Paris.

Gravez, V. \& Bernard G. (2006). Pollution marine: Les définitions. www. com.univ-mrs.fr.

Guardiola, F.A., Chaves-Pozo, E., Espinosa, C., Romero, R., Meseguer, J. Cuesta, A. \& Esteban M.A. (2016). Mercury accumulation, structural damages, and antioxidant and immune status changes in the gilthead seabream (Sparus aurata L.) exposed to methylmercury. Arch. Environ. Contam. Toxicol., 70, 734-746. DOI: 10.1007/s00244-016-0268-6.

Henry, F., Amara, R., Courcot, L., Lacouture, D. \& Bertho M.L. (2004). Heavy metals in four fish species from the French coast of the Eastern English Channel and Southern Bight of the North Sea. Environment International, 30(5), 675-683. DOI: 10.1016/j.envint.2003.12.007.

Huang, H., Wu, J.Y. \& Wu J.H. (2007). Heavy metal monitoring using bivalved shellfish from Zhejiang coastal waters, East China Sea. Envi ron. Monit. Assess., 129, 315-320. DOI: 10.1007/s10661-006-9364-9.

I.A.E.A (2004). Trace elements and methylmercury in fish tissue. Reference material. Vienna: IAEA.

INERIS (2005). Fiche de données toxicologiques environnementales des substances chimiques, cadmium et ses derives. INERIS-DRC-0125590-00DF249.doc. Version N²-3 Fevrier 05.

IOPR (1996). Fragile méditerranée. Reconquête d'un équilibre écologique. Doc. Institut Océanographique Paul Ricard. Edisud, Aix-en-provence.

JORADP N²5 (2011). Journal Officielle de la République Algérienne $\mathrm{N}^{\circ} 25$. Annexe I : Seuils limites des contaminants chimiques. Ministère de la Pêche et de Ressources Halieutiques.

Kalay, M. \& Canli M. (2000). Elimination of essential (Cu, Zn) and nonessential $(\mathrm{Cd}, \mathrm{Pb})$ metals from tissue of a freshwater fish Tilapia zilli. Turk. J. Zool., 24, 429-436.

Kayalto, B., Mbofung, C.M, Tchatchueng, J. \& Ahmed A. (2014). Contribution à l'évaluation de la contamination par les métaux lourds de trois espèces de poissons, des sédiments et des eaux du Lac Tchad. International Journal of Biological and Chemical Sciences, 8(2), 468-480. DOI: 10.4314 /ijbcs.v8i2.7.

Lacoue-Labarthe, T., Réveillac, E., Oberhansli, F., Teyssié, J.L., Jeffree, R. \& Gattuso J.P. (2011). Effects of ocean acidification on trac element accumulation in the early-life stages of squid Loligo vulgaris. Aquat. Toxicol., 105, 166-176. DOI: 10.1016/j.aquatox.2011.05.021.

Lafabrie, C., Pergent, G., Kantin, R., Pergent-Martini, C. \& Gonzalez J.L. (2007). Trace metals assessment in water, sediment, mussel and seagrass species- Validation of the use of Posidonia oceanica as a metal biomonitor. Chemosphere, 68(11), 2033-2039. DOI: 10.1016/j.chemosphere.2007.02.039

Lannin, A. (2006). The biology, dynamics and fisheries for hake (Merluc cius merluccius) in the waters around Ireland. $\mathrm{PhD}$ thesis, University College Cork.

Leroy, L. (2006). Lutte contre les salissures marines: approche par procédés enzymatiques. Thèse de Doctorat, Institut National des Sciences Appliquées de Toulouse.

Lucio, P., Murua, H. \& Santurtun M. (2000). Growth and reproduction of hake (Merluccius merluccius) in the Bay of Biscay during the period 1996-1997. Ozeanografika, 3, 325-354.

Marcovecchio, J.E. \& Moreno V.J. (1993). Cadmium, zinc and total mercury levels in the tissues of several fish species from La-Plata River estuary, Argentina. Environ. Monit. Assess., 25, 119-130. DOI: 10.1007/BF00549133.

Mason, L.H, Harp, J.P. \& Han D.Y. (2014). Pb neurotoxicity: Neuropsychological effects of lead toxicity. BioMed Research International, 2014, 840547. DOI: $10.1155 / 2014 / 840547$.

Mellon-Duval, C., de Pontual, H., Métral, L. \& Quemener L. (2010). Growth of European hake (Merluccius merluccius) in the Gulf of Lions based on conventional tagging. ICES J. Mar. Sci., 67(1), 62-70. DOI: $10.1093 /$ icesjms/fsp215.
Morales-Nin, B. \& Moranta J. (2004). Recruitement and post-settlement growth of juvenile Merluccius merluccius on the western Mediterranean shelf. Sci. Mar., 68(3), 399-409. DOI: 10.3989/ scimar.2004.68n3399.

Murua, H., Lucio, P., Santurtún, M. \& Motos L. (2006). Seasonal variation in egg production and batch fecundity of European hake Merluccius merluccius (L.) in the Bay of Biscay. J. Fish Biol., 69, 1304-1316. DOI 10.1111/j.1095-8649.2006.01209.x.

Nacer, H.A. (2013). Assessment and management of heavy metal pollution in the marine environment of the Arabian Gulf. Mar. Pollut. Bull., 72(1), 6-13. DOI: 10.1016/j.marpolbul.2013.04.030.

NHMRC (1992). National Health and Medical Research Council act 1992. Act No. 225: 1-82. https://www.legislation.gov.au/Details/ C2006C00354.

Nsimanda, I.C., Musibono, E.D., Basosila, L.N. \& Wanga B.M.B. (2015) Preliminary study on the fish contamination with the lead and cadmium from the Malebo Pool (Congo River, Kinshasa, DR Congo): Distichodus fasciolatus, Mormyrops anguilloides and Schilbe mistus (pisces). International Journal of Innovation and Applied Studies, 10(1), 176-183. http://www.ijias.issr-journals.org/.

Ohta, H., Ichikawa, M. \& Seki Y. (2002). Effects of cadmium intake on bone metabolism of mothers during pregnancy and lactation. Tohoku J. Exp. Med., 196(1), 33-42. DOI: 10.1620/tjem.196.33.

OMS-IPCS (1998). Environmental health criteria $n^{\circ} 200$. Copper: International Programme on Chemical Safety. http://www.inchem.org/documents/ehc/ehc/ehc200.

Onistratenko, N.V., Ivantsova, E.A., Denysov, A.A. \& Solodnikov D.A (2016). Heavy metals in suburban ecosystems of industrial centers and ways of their reduction. Ekológia (Bratislava), 35(3), 205-212. DOI: 10.1515/eko-2016-0016.

Onivogui, G., Balde, S., Bangoura, K. \& Barry M.K. (2013). Évaluation des risques de pollution en métaux lourds $(\mathrm{Hg}, \mathrm{Cd}, \mathrm{Pb}, \mathrm{Co}, \mathrm{Ni}, \mathrm{Zn})$ des eaux et des sédiments de l'estuaire du fleuve Konkouré (Rep. de Guinée). Afrique Science, 09(3), 36-44. http://www.afriquescience. info/.

Orban, E., Lena, G.di., Nevigato, T., Casini, I., Marzetti, A. \& Caproni R. (2002). Seasonal changes in meat content, condition index and chemical composition of mussels (Mytilus galloprovincialis) cultured in two different Italian sites. Food Chem., 77(1), 57-65. DOI: 10.1016/S0308-8146(01)00322-3.

Ouali, N., Belabed, B.E. \& Chenchouni O. (2018). Modelling environment contamination with heavy metals in flathead grey mullet Mugil cephalus and upper sediments from north African coasts of the Mediterranean Sea. Sci. Total Environ., 639, 156-174. DOI: 10.1016/j.scitotenv.2018.04.377.

Öztürk, M., Özözen, G., Minareci, O. \& Minareci E. (2009). Determination of heavy metals in fish, water and sediments of Avsar Dam lake in Turkey. Iranian Journal of Environmental Health Science and Engineering, 6(2), 73-80

Piñeiro, C. \& Saínza M. (2003). Age estimation, growth and maturity of the European hake (Merluccius merluccius Linnaeus, 1758) from Iberian Atlantic waters. ICES J. Mar. Sci., 60(5), 1086-1102. DOI 10.1016/S1054-3139(03)00086-9.

Pouil, S., Teyssié, J-L., Rouleau, C., Fowler, S., Metian, M., Bustamante, P. \& Warnau M. (2017). Comparative study of trophic transfer of the essential metals $\mathrm{Co}$ and $\mathrm{Zn}$ in two tropical fish: a radiotracer approach. J. Exp. Mar. Biol. Ecol., 486, 42-51. DOI: 10.1016/j.jembe.2016.09.005

Powell, J.H., Powell, R.E. \& Fielder D.R. (1981). Trace elements concentrations in tropical marine fish at Bougaiville, Island, Papua New Guinea. Water Air Soil Pollut., 16(2), 143-158. DOI: 10.1007/BF01046851.

Ramade, F. (1992). Précis d'écotoxicologie. Paris: Edité par Masson.

Recasens, L., Lombarte, A., Morales-Nin, B. \& Torres G.J. (1998). Spatiotemporal variation in the population structure of the European hake in the NW Mediterranean. J. Fish Biol., 53(2), 387-401. DOI: 10.1111/j.1095-8649.1998.tb00988.x.

Ribeiro, C.A., Vollaire, Y., Sanchez-Chardi, A. \& Roche H. (2005).Bioaccumulation and the effects of organochlorine pesticides, PHA and heavy metals in the Eel (Anguilla anguilla) at the Camargue Nature Reserve, France. Aquat. Toxicol., 74(1), 53-69. DOI: 10.1016/j.aquatox.2005.04.008. 
Rouane-Hacene, O., Abdelghani, F. \& Boutiba Z. (2008). Evaluation of organoclorinated compounds in Hake (Merluccius merluccius L., 1758) from Algerian western coast. Actsof International Conference on Modelling \& Monitoring of Marine Pollution (pp. 184-189). Kish UNOC-INCO.

Ruilian, Y., Xing, Y., Yuanhui, Z., Gongren, H. \& Xianglin T. (2008). Heavy metal pollution in intertidal sediments from quanzhou Bay, China. $J$. Environ. Sci., 20(6), 664-669. DOI: 10.1016/s1001-0742(08)62110-5.

Sarano, F. (1986). Cycle ovarien du merlu, Merluccius merluccius L. 1758, poisson à ponte fractionnée. Revue des Travaux de l'Institut des Pêches Maritimes, 48(1-2), 65-76.

Storelli, M., Storelli, A., Giacominelli-Stuffler, R. \& Marcotrigiano G. (2005). Mercury speciation in the muscle of two commercially important fish, hake (Merluccius merluccius) and striped mullet ( $M u l-$ lus barbatus) from the Mediterranean sea: Estimated weekly intake. Food Chem., 89(2), 295-300. DOI: 10.1016/j.foodchem.2004.02.036.

Webb, M. (1997). The metallothioneins, in the chemistry, biochemistry and biology of cadmium. In M. Webb (Ed.), Topics in environmental heath (pp. 195-266). Amsterdam: Elsevier.
WHO (1993). International Programme on Chemical Safety (IPCS), Environmental Health Criteria 155-Biomarkers and risk assessment: Concept and principles, Geneva, World Health Organization.

Yi, Y., Yang, Z. \& Zhang S. (2011). Ecological risk assessment of heavy metals in sediment and human health risk assessment of heavy metals in fishes in the middle and lower reaches of the Yangtze River basin. Environ. Pollut., 159(10), 2575-2585. DOI: 10.1016/j. envpol.2011.06.011.

Yigit, S. \& Altindag A. (2006). Concentration of heavy metals in the food web of Lake Egirdir, Turkey. J. Environ. Biol., 27(3), 475-478. www. jeb.co.in

Yilmaz, F. (2009). The comparison of heavy metal concentrations (Cd $\mathrm{Cu}, \mathrm{Mn}, \mathrm{Pb}$, and $\mathrm{Zn}$ ) in tissues of three economically important fish (Anguilla anguilla, Mugil cephalus and Oreochromis niloticus) Inhabiting Koycegiz Lake-Mugla (Turkey). Turkish Journal of Science and Technology, 4(1), 7-15. 